\title{
KEMAMPUAN KONEKSI MATEMATIKA SISWA DALAM MENYELESAIKAN SOAL MATEMATIKA BENTUK CERITA DITINJAU DARI KEMAMPUAN AWAL MATEMATIKA SISWA SMP NEGERI 1 MAJENE
}

\begin{abstract}
Amran Yahya*
ABSTRACT

The type of this research is descriptive research that aims to determine the ability of students mathematical connections to solve the problem of story form on Triangle and Triangle material in class VII of SMP Negeri 1 Majene based on students' early math ability. The subjects of the study were 6 students consisting of 2 students with a high level of early math ability, 2 students with moderate level of math ability, and 2 students with low level of early math ability. The result of the research shows that (1) students with high level of high mathematics ability have high mathematical connection ability, students with high ability level can solve problems and connect them with mathematics, science (other), and daily life well. But there are students who have little problem in solving the problem (2) students with the basic level of mathematics skills have medium math connection ability, students with ability level are able to understand the problem, but have difficulty in solving the problem and connect it with mathematics concept, fields), and daily life. (3) students with low level of early math ability have low mathematical connection ability, Students with low ability level have difficulty in understanding determine the elements of the problem so that they can not solve the problem and connect it with mathematics, science (other), and also everyday life.
\end{abstract}

Keywords: mathematical connections, early math skills, verbal test

\section{PENDAHULUAN}

Salah satu harapan yang ingin dicapai dalam pembelajaran matematika di Sekolah Menengah Pertama (SMP) adalah setiap siswa memiliki kemampuan berpikir matematika. Istilah berpikir matematika memuat arti cara berpikir yang berkaitan dengan karakteristik matematika. Oleh karena itu, pembahasan

*) Prodi Pendidikan Matematika, Universitas Sulawesi Barat, E-mail: amranyahya53@gmail.com 
tentang berpikir matematika berkaitan erat dengan hakikat matematika itu sendiri. National Counsil of Teacher of Mathematics (NCTM 2000) dalam Dossey et.al (2002: 71) menyatakan bahwa ada beberapa aspek yang termasuk dalam kemampuan berpikir matematika di antaranya adalah Mathematics as problem solving (matematika sebagai pemecahan masalah), Mathematics as reasoning and proof (matematika sebagai penalaran dan pembuktian), Mathematics as Communication (matematika sebagai komunikasi), Mathematics as Connections (matematika sebagai koneksi) dan Mathematics as Representations (matematika sebagai representasi).

Dari kelima kemampuan berpikir matematika tersebut, dengan tidak mengabaikan kemampuan yang lain kemampuan matematika sebagai koneksi atau kemampuan koneksi matematika merupakan bagian penting dalam aktivitas dan penggunaan matematika yang dipelajari siswa. Pentingnya kemampuan ini dijelaskan dalam standar kompetensi bahan kajian matematika kurikulum yang berlaku saat ini pada tingkat Sekolah Menengah Pertama (SMP). Dalam standar ini dijelaskan bahwa siswa dituntut untuk memiliki kemampuan menghubungkan gagasan dengan simbol, skema, tabel, grafik atau diagram untuk memperjelas suatu keadaan atau masalah, menunjukkan kemampuan dalam membuat, menafsirkan, dan menyelesaikan model matematika dalam pemecahan masalah, dan memiliki sikap menghargai kegunaan matematika dalam kehidupan sehari-hari.

NCTM mengemukakan koneksi matematika (mathematical connection) membantu siswa untuk mengembangkan perspektifnya, memandang matematika sebagai suatu bagian yang terintegrasi daripada sebagai sekumpulan topik, serta mengakui adanya relevansi dan aplikasi baik di dalam kelas maupun di luar kelas. Selanjutnya, Sumarmo (2005) merinci kemampuan yang tergolong dalam kemampuan koneksi matematik di antaranya adalah: Mencari hubungan berbagai representasi konsep dan prosedur; memahami hubungan antar topik matematika; menerapkan matematika dalam bidang lain atau dalam kehidupan sehari-hari; memahami representasi ekuivalen suatu konsep; mencari hubungan satu prosedur dengan prosedur lain dalam representasi yang ekuivalen; dan menerapkan hubungan antar topik matematika dan antara topik matematika dengan topik di luar matematika.

Tetapi kenyataannya, siswa masih kesulitan dalam menyelesaikan soal terkait menuliskan masalah kehidupan sehari-hari ke dalam bentuk model matematika. Siswa juga masih kesulitan dalam menghubungkan antar obyek dan konsep dalam matematika. Selain itu, siswa juga masih kesulitan dalam menentukan rumus apa yang akan dipakai jika dihadapkan pada soal-soal yang 
berkaitan dengan masalah kehidupan sehari-hari. Sebagian besar siswa memiliki kemampuan koneksi matematis yang masih rendah. Hal ini ditunjukkan dengan kekurangmampuan siswa dalam menyelesaikan soal terkait dengan koneksi matematika, seperti berikut.

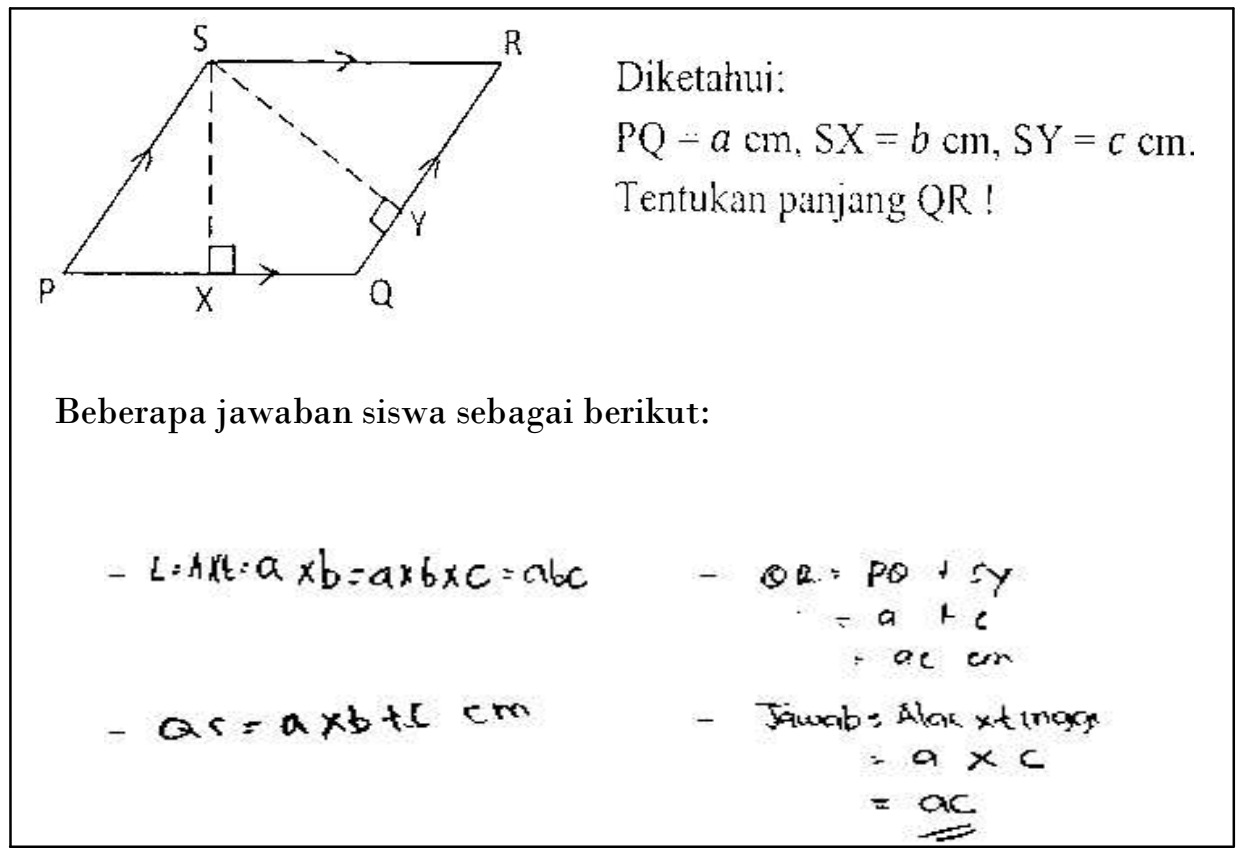

Gambar 1. Contoh Penyelesaian Soal Siswa

Berdasarkan beberapa jawaban ini, dapat terlihat siswa belum mengenali representasi konsep alas dan tinggi dari suatu bangun datar. Kelemahan siswa terletak ketika menentukan alas jika tingginya adalah SY.

Salah satu materi dalam kurikulum SMP yang sering dijumpai pada permasalahan dalam kehidupan sehari-hari serta pada ilmu lain seperti arsitek adalah segitiga dan segi empat yang berhubungan dengan luas dan keliling. Materi segitiga dan segi empat dapat digunakan sebagai alat bantu dalam perhitungan suatu proyek atau pekerjaan. Permasalahan kehidupan sehari-hari yang berhubungan dengan angka dan perhitungan dituangkan dalam soal matematika dalam bentuk cerita. Soal matematika bentuk cerita merupakan soal bentuk soal uraian yang dapat digunakan untuk mengukur kemampuan 
siswa siswa serta melatih siswa dengan kemampuan pemecahan masalah, merumuskan hipotesis, menyusun dan mengekspresikan gagasannya dan menarik kesimpulan.

Soal bentuk uraian juga dapat melatih kemampuan berpikir terartur atau penalaran, yakni berpikir logis, analitis, dan sistematis. Soal matematika dalam bentuk cerita memberikan gambaran yang nyata mengenai permasalahan kehidupan yang sebenarnya. Sehingga pemberian soal bentuk cerita dapat dijadikan salah satu alat ukur kemampuan koneksi matematika siswa.

Berdasarkan latar belakang masalah tersebut maka peneliti merasa terdorong untuk melakukan penelitian tentang "Kemampuan koneksi matematika siswa dalam menyelesaikan soal bentuk cerita matematika ditinjau dari kemampuan dasar matematika siswa kelas VII SMP Negeri 1 Majene”.

\section{METODE PENELITIAN}

\section{a. Jenis penelitian}

Pada penelitian ini peneliti menggunakan penelitian deskriptif dengan menggunakan pendekatan kualitatif. Penelitian deskriptif adalah penelitian yang melukiskan dan menafsirkan keadaan yang ada sekarang (Furchan, 2011: 39). Penelitian ini dipilih dengan alasan penulis akan memaparkan data yang diperoleh melalui hasil tes soal yang diberikan pada siswa. Penelitian ini dilakukan untuk mengetahui kemampuan koneksi matematika siswa menyelesaikan soal bentuk cerita pada materi Segitiga dan Segi Empat di kelas VII SMP Negeri 1 Majene.

\section{b. Subjek penelitian}

Jumlah subjek dalam penelitian ini adalah 6 orang siswa, yang dipilih berdasarkan tingkat kemampuan dasar matematika, terdiri dari 2 siswa dengan tingkat kemampuan tinggi, 2 siswa dengan tingkat kemampuan sedang, serta 2 siswa dengan kemampuan rendah.

\section{c. Instrumen penelitian}

1. Instrumen utama adalah peneliti. Guba \& Lincoln (Arifin, 2014: 169) menegaskan "apabila metode penelitian telah jelas kualitatif, maka instrumen yang digunakan, yaitu manusia, dalam hal ini peneliti sendiri". Peneliti merupakan perencana, pelaksanaan pengumpulan data, analis, penafsir data, dan menjadi pelapor hasil penelitiannya.

2. Studi dokumentasi. Dokumen artinya bahan-bahan tertulis. Studi dokumentasi adalah teknik untuk mempelajari dan menganalisi bahanbahan tertulis kantor atau sekolah, seperti: silabus, program tahunan, program bulanan, program mingguan, rencana pelaksanaan pembelajaran 
(RPP), catatan pribadi peserta didik, buku raport, kisi-kisi, daftar nilai, lembar soal/tugas, lembar jawaban, dan lain-lain. (Arifin, 2014: 243). Adapun dokumentasi yang digunakan dalam penelitian ini adalah dokumentasi berupa nilai ujian akhir semester ganjil siswa kelas VII SMP Negeri 1 Majene.

3. Tes adalah suatu teknik pengukuran yang didalamnya terdapat berbagai pertanyaan, pernyataan, atau srangkaian tugas yang harus dikerjakan atau dijawab oleh responden (Arifin, 2014: 226). Adapun tes yang digunakan dalam penelitian ini adalah tes kemampuan koneksi matematis. Tes tersebut berupa soal matematika bentuk cerita. Tujuan dari tes tersebut untuk mengetahui tingkat kemampuan koneksi matematis siswa dalam menyelesaikan soal-soal geometri tentang segitiga dan segi empat dengan memperhatikan kategori kemampuan dasar matematika siswa.

d. Teknik pengumpulan data

Teknik yang digunakan peneliti dalam penelitian ini adalah:

1. Tes, dalam penelitian ini tes digunakan untuk mengetahui sejauh mana ketuntasan hasil belajar siswa dan kemampuan koneksi matematis siswa dalam memecahkan soal bentuk cerita materi geometri siswa kelas VII SMP. Tes diberikan oleh peneliti kepada siswa setelah proses pembelajaran selesai berupa uraian.

2. Wawancara, ada dua jenis wawancara, yakni wawancara berstruktur dan wawancara tak berstruktur (Furchan, 2011: 259). Dalam penelitian ini peneliti menggunakan wawancara tak terstruktur.

3. Dokumentasi, Dokumen yang digunakan peneliti disini berupa foto, gambar, serta data-data mengenai siswa kelas VII SMP Negeri 1 Majene yang diperoleh dari guru matematika yang mengajar pada kelas tersebut. Hasil penelitian dan wawancara akan semakin sah dan dapat dipercaya apabila didukung oleh foto-foto atau gambar.

\section{e. Teknik analisis data}

Model analisis data dalam penelitian ini mengikuti konsep yang diberikan Miles and Huberman (Sugiyono, 2008: 91) mengungkapkan bahwa aktifitas dalam analisis data kualitatif dilakukan secara interaktif dan berlangsung secara terus-menerus pada setiap tahapan penelitian sehingga sampai tuntas.

1. Reduksi data

Data yang diperoleh dari laporan jumlahnya cukup banyak, untuk itu maka perlu dicatat secara teliti dan rinci. Mereduksi data berarti merangkum, memilih hal-hal pokok, memfokuskan pada hal-hal yang penting, dicari tema dan polanya. 


\section{Penyajian Data}

Penyajian data penelitian kualitatif bisa dilakukan dalam bentuk uraian singkat bagan, hubungan antar kategori, dan sejenisnya.

3. Penarikan kesimpulan (verifikasi)

Kesimpulan awal yang dikemukakan masih bersifat sementara, dan akan berubah bila ditemukan bukti-bukti yang kuat yang mendukung pada tahap berikutnya. Tetapi apabila kesimpulan yang dikemukakan pada tahap awal, didukung oleh bukti-bukti yang valid dan konsisten saat peneliti kembali kelapangan mengumpulkan data, maka kesimpulan yang dikemukakan merupakan kesimpulan yang kredibel.

\section{f. Pemeriksaan keabsahan data}

Untuk menguji kredibilitas data penelitian peneliti menggunakan teknik Triangulasi. Trianggulasi dengan sumber artinya membandingkan dan mengecek balik derajat kepercayaan suatu informasi yang diperoleh melalui waktu dan alat yang berbeda dalam penelitian kualitatif. Setelah penulis melakukan penelitian dengan menggunakan metode tes, wawancara, dan dokumentasi, kemudian data hasil dari penelitian itu digabungkan sehingga saling melengkapi.

\section{HASIL PENELITIAN DAN PEMBAHASAN}

\section{a. Hasil Penelitian}

1. Aspek menggunakan koneksi antar topik dalam matematika

Hasil tes kemampuan koneksi antar topik dalam matematika, sebagai berikut:

\subsection{Subjek dengan tingkat kemampuan awal matematika kategori tinggi}

Berdasarkan data dan cuplikan wawancara pada subjek T1 dan T2 yang merupakan siswa yang berada pada kategori kemampuan awal matematika tinggi, menunjukkan bahwa kedua subjek memiliki kemampuan koneksi matematika pada aspek koneksi antar topik dalam matematika yang tinggi, tetapi kedua subjek memiliki perbedaan dalam proses pengerjaan soal, subjek T1 mengerjakan soal secara rinci dan sistematis sedangkan subjek T2 hanya menuliskan jawaban tanpa menuliskan unsur dan konsep yang digunakan.

\subsection{Subjek dengan tingkat kemampuan awal matematika kategori sedang}

Berdasarkan data dan cuplikan wawancara pada subjek S1 dan subjek S2 yang merupakan siswa yang berada pada kategori kemampuan awal matematika sedang, terlihat perbedaan dalam kemampuan koneksi antar topik dalam matematika. Subjek S1 mampu dalam memahami maksud dari soal serta mengkoneksikannya dengan konsep-konsep dari bangun datar, sedangkan subjek S2 tidak mampu dalam memahami dan menerjemahkan maksud dari soal. 
Kemampuan koneksi aspek antar topik dalam matematika subjek S1 berada pada kategori tinggi sedangkan subjek S2 pada kategori rendah.

\subsection{Subjek dengan tingkat kemampuan awal matematika kategori rendah}

Berdasarkan data dan cuplikan wawancara pada subjek $\mathrm{R} 1$ dan subjek R2 yang merupakan siswa yang berada pada kategori kemampuan dasar matematika rendah, kedua subjek mengalami kesulitan dalam memahami maksud dari soal.

\section{Aspek koneksi matematika dengan ilmu (bidang) lain}

Hasil tes kemampuan koneksi matematika dengan ilmu (bidang) lain setiap subjek penelitian, sebagai berikut:

\subsection{Subjek dengan tingkat kemampuan awal matematika kategori tinggi}

Berdasarkan data dan cuplikan wawancara pada subjek T1 dan subjek T2 yang merupakan siswa yang berada pada kategori kemampuan awal matematika tinggi, menunjukkan bahwa kedua subjek memiliki kemampuan koneksi matematika pada aspek koneksi matematika dengan ilmu (bidang) lain pada kategori sedang. Kedua subjek berbeda dalam menentukan unsur yang diketahui.

\subsection{Subjek dengan tingkat kemampuan awal matematika kategori sedang}

Berdasarkan data pada subjek S1 dan subjek S2 yang merupakan siswa yang berada pada kategori kemampuan dasar matematika sedang, terlihat perbedaan dalam kemampuan koneksi antar topik dalam matematika. Subjek S1 mampu menuliskan sebagian unsur dari soal tetapi tidak tepat dalam mengkoneksikannya dengan konsep-konsep dari bangun datar, sedangkan subjek S2 tidak mampu dalam memahami dan menerjemahkan maksud dari soal. Kemampuan koneksi aspek antar topik dalam matematika subjek S1 berada pada kategori sedang sedangkan subjek S2 pada kategori rendah.

\subsection{Subjek dengan tingkat kemampuan dasar matematika kategori rendah}

Pada aspek koneksi matematika dengan ilmu (bidang) lain terlihat bahwa kemampuan koneksi matematika yang ditunjukkan oleh subjek sedikit berbeda dengan tingkat kemampuan awal matematika siswa, subjek dengan kemampuan dasar matematika tinggi memiliki kemampuan koneksi matematika dengan ilmu (bidang) lain pada kategori sedang, subjek dengan tingkat kemampuan sedang memiliki kemampuan koneksi sedang dan subjek dengan tingkat kemampuan rendah memiliki kemampuan koneksi antar topik yang rendah. Akan tetapi kemampuan subjek S2 dalam koneksi matematika dengan ilmu (bidang) lain berada pada kategori rendah, dan subjek R1 berada pada kategori sedang. 


\section{Aspek koneksi matematika dengan kehidupan sehari-hari}

Hasil tes kemampuan koneksi matematika dengan kehidupan sehari-hari, sebagai berikut:

\subsection{Subjek dengan tingkat kemampuan awal matematika kategori tinggi}

Hasil validasi data tes kemampuan koneksi dengan wawancara pada subjek T1 dan subjek T2 yang merupakan siswa yang berada pada kategori kemampuan awal matematika tinggi, menunjukkan bahwa subjek T1 dan T2 memiliki kemampuan koneksi matematika dengan kehidupan sehari-hari kategori tinggi.

\subsection{Subjek dengan tingkat kemampuan awal matematika kategori sedang}

Hasil validasi data tes kemampuan koneksi dengan wawancara pada subjek S1 dan subjek S2 yang merupakan siswa yang berada pada kategori kemampuan awal matematika sedang, menunjukkan bahwa Subjek S1 dan S2 memiliki kemampuan koneksi matematika dengan kehidupan sehari-hari kategori sedang.

\subsection{Subjek dengan tingkat kemampuan awal matematika kategori rendah}

Pada aspek koneksi matematika dengan kehidupan sehari-hari, terlihat bahwa kemampuan subjek dengan tingkat kamampuan awal matematika tinggi memiliki kemampuan koneksi matematika dengan kehidupan sehari-hari yang tinggi, subjek dengan tingkat kemampuan awal matematika sedang, memilki kemampuan koneksi matematika dengan kehidupan sehari-hari kategori sedang. Sedangkan subjek dengan tingkat kemampuan awal matematika rendah menunjukkan kemampuan koneksi matematika dengan kehidupan sehari-hari yang rendah.

Rangkuman hasil analisis data hasil tes kemampuan koneksi matematika serta wawancara terhadap subjek penelitian dituliskan dalam tabel 1 berikut:

Tabel 1. Hasil Analisis Data Tes Kemampuan Koneksi dengan Wawancara

\begin{tabular}{|c|l|l|l|}
\hline & $\begin{array}{c}\text { Koneksi antar } \\
\text { topik }\end{array}$ & $\begin{array}{c}\text { Koneksi dengan } \\
\text { ilmu (bidang) } \\
\text { lain }\end{array}$ & $\begin{array}{c}\text { Koneksi dengan } \\
\text { kehidupan sehari-hari }\end{array}$ \\
\hline $\begin{array}{c}\text { Kemampuan awal } \\
\text { matematika tinggi }\end{array}$ & Tinggi & Sedang & Tinggi \\
\hline $\begin{array}{c}\text { Kemampuan awal } \\
\text { matematika } \\
\text { sedang }\end{array}$ & Sedang & Rendah & Sedang \\
\hline $\begin{array}{c}\text { Kemampuan awal } \\
\text { matematika } \\
\text { rendah }\end{array}$ & Rendah & Rendah & Rendah \\
\hline
\end{tabular}




\section{b. Pembahasan Hasil Pelaksanaan Penelitian}

1. Kemampuan koneksi matematika siswa

\subsection{Aspek koneksi antar konsep matematika}

Yang dimaksud dengan kemampuan koneksi antar konsep dalam matematika adalah sanggup untuk mengkaitkan antar konsep-konsep yang ada dalam satu materi. Dalam penelitian ini, materi yang diteliti adalah bangun datar, sehingga yang dimaksud dengan kemampuan koneksi antar ide-ide dalam matematika adalah dapat mengkaitkan antar konsep yang ada dalam materi bangun datar. Kemampuan ini dilihat berdasarkan kesanggupan dan ketepatan siswa dalam menggunakan konsep bangun datar untuk mendapatkan unsur yang ditanyakan dengan memanfaatkan unsur yang sudah diketahui pada soal yang diberikan.

Dari hasil tes yeng diberikan terhadap siswa, berupa tes kemampuan koneksi matematika soal bentuk cerita, kebanyakan siswa telah memahami hubungan antara ide-ide dalam materi pelajaran matematika, hal ini terlihat dari kemampuan siswa dalam menentukan unsur-unsur yang diketahui. Pada siswa yang berada pada kategori kategori tinggi mampu menyelesaikan soal dengan baik, sedangkan untuk siswa kategori sedang telah mampu menentukan unsur-unsur dengan baik meskipun masih ada beberapa yang jawabannya kurang tepat, tetapi untuk siswa dengan kategori rendah mengalami kesulitan dalam memahami soal-soal yang diberikan.

Pada aspek koneksi antar topik dalam matematika terlihat subjek T1 memiliki kemampuan koneksi matematika tinggi, T2 kemampuan koneksi tinggi, S1 kemampuan koneksi tinggi, S2 kemampuan koneksi rendah, R1 kemampuan koneksi rendah, serta R2 kemampuan koneksi rendah. Secara keseluruhan subjek dengan kemampuan awal matematika tinggi memiliki kemampuan koneksi antar topik matematika yang tinggi, subjek dengan kemampuan awal matematika sedang memiliki kemampuan koneksi antar topik matematika kategori sedang, dan subjek dengan kemampuan awal matematika rendah memiliki kemampuan koneksi antar topik matematika kategori rendah.

\subsection{Aspek koneksi matematika dengan ilmu (bidang) lain}

Dalam penelitian ini, materi yang diteliti adalah bangun datar, sehingga yang dimaksud dengan mengkoneksikan matematika dengan mata pelajaran lain adalah dapat menyelesaikan masalah pada materi bangun datar yang terdapat hubungan dengan mata pelajaran lain dengan membentuk model matematika.

Dari hasil tes yang telah diberikan, siswa kurang mampu dalam menyelesaikan soal. Pada aspek ini siswa yang berada pada kategori kemampuan dasar tinggi masih mampu menyelesaikan soal dengan baik, tetapi terdapat 
siswa yang tidak dapat merumuskan penyelesaian dengan tepat. Siswa pada kategori sedang, juga mengalami kesulitan dalam menyelesaikan soal yang diberikan, sedangkan untuk siswa pada kategori rendah terdapat siswa yang tidak mampu memahami maksud dari soal yang diberikan.

\subsection{Aspek matematika dengan kehidupan sehari-hari}

Yang dimaksud dengan mengkoneksikan matematika ke dalam kehidupan sehari-hari adalah menggunakan konsep matematika untuk menyelesaikan masalah yang berhubungan dengan masalah sehari-hari. Dalam penelitian ini, materi yang diteliti adalah bangun ruang sisi datar, sehingga yang dimaksud dengan mengaplikasikan matematika ke dalam kehidupan sehari-hari adalah dapat menyelesaikan masalah realistis pada materi bangun datar dengan membentuk model matematika. Kemampuan ini dapat dilihat dengan kesanggupan siswa dalam menyelesaikan soal yang berhubungan dengan kehidupan sehari-hari, karena siswa dapat berfikir realistis.

Dari hasil tes yang telah diberikan, siswa cukup mampu dalam membentuk model matematika dari permasalahan yang terdapat pada soal. Pada aspek ini siswa yang berada pada kategori kemampuan awal tinggi masih mampu menyelesaikan soal dengan baik, tetapi terdapat siswa yang tidak dapat merumuskan penyelesaian dengan tepat. Siswa pada kategori sedang, dapat menyelesaikan soal yang diberikan dengan membentuk model matematika meskiput belum tepat, sedangkan untuk siswa pada kategori rendah mampu menentukan unsur yang diketahui tetapi kesulitan dalam mengubahnya dalam model matematika. Namun terdapat siswa yang tidak mampu memahami maksud dari soal yang diberikan.

Pada aspek koneksi matematika dengan kehidupan sehari-hari terlihat subjek T1 memiliki kemampuan koneksi tinggi, T2 kemampuan koneksi tinggi, S1 kemampuan koneksi sedang, S2 kemampuan koneksi sedang, R1 kemampuan koneksi sedang, serta R2 kemampuan koneksi rendah. Secara keseluruhan subjek dengan kemampuan awal matematika tinggi memiliki kemampuan koneksi matematika dengan kehidupan sehari-hari kategori tinggi, subjek dengan kemampuan awal matematika sedang memiliki kemampuan koneksi matematika dengan kehidupan sehari-hari kategori sedang, dan subjek dengan kemampuan awal matematika rendah memiliki kemampuan koneksi matematika dengan kehidupan sehari-hari kategori rendah. 


\section{SIMPULAN}

Berdasarkan analisis pada Bab IV, maka "deskripsi kemampuan koneksi matematika dalam menyelesaikan soal matematika bentuk cerita materi bangun datar" diperoleh sebagai berikut:

1. Siswa dengan tingkat kemampuan awal matematika tinggi mampu meyelesaikan permasalahan dan mengkoneksikannya dengan konsep matematika, ilmu (bidang) lain, serta kehidupan sehari-hari dengan baik. Tetapi terdapat siswa yang mengalami sedikit hambatan dalam menyelesaikan soal.

2. Siswa dengan tingkat kemampuan awal matematika sedang mampu memahami soal, tetapi mengalami kesulitan dalam menyelesaikan permasalahan dan mengkoneksikannya dengan konsep matematika, ilmu (bidang) lain, serta kehidupan sehari-hari.

3. Siswa dengan tingkat kemampuan awal matematika rendah mengalami kesulitan dalam memahami menentukan unsur-unsur dari soal sehingga tidak dapat menyelesaikan permasalahan serta mengkoneksikannya dengan konsep matematika, ilmu (bidang) lain, serta kehidupan sehari-hari

\section{SARAN DAN REKOMENDASI}

Berdasarkan kesimpulan yang dikemukakan diatas, maka terdapat saran yang perlu disampaikan sebagai berikut.

1. Para peneliti untuk dapat menindaklanjuti hasil dan temuan-temuan dalam penelitian ini. Serta diharapkan dapat melaksanakan penelitian lanjutan dengan beragam soal koneksi matematis, sehingga dapat memperbaiki kemampuan koneksi matematis siswa.

2. Guru atau praktisi pendidikan lainnya dalam memberikan materi serta latihan tes terhadap siswa, agar lebih banyak memberikan permasalahan yang dapat mendorong siswa dalam meningkatkan kemampuan berpikir matematika, sehingga dapat membantu siswa dalam meningkatkan kemampuan pemecahan masalah serta kemampuan koneksi matematikanya.

\section{DAFTAR PUSTAKA}

Abdurrahman, Mulyono. 2003. Pendidikan bagi Anak Berkesulitan Belajar. Jakarta: Rineka Cipta.

Arifin, Zainal. 2014. Penelitian Pendidikan "Metode dan Paradigma Baru". Bandung: Remaja Rosdakarya. 
Depdiknas. 2006. Tentang Kurikulum Tingkat Satuan Pendidikan (KTSP). Jakarta: Depdiknas.

Dossey, J. A. et al. 2002. Mathematics methods and Modeling for Today's Mathematics Classroom. Canada: Thomson learning.

Furchan, Arief. 2011. Pengantar Penelitian Dalam Pendidikan. Yogyakarta. Pustaka Pelajar.

Sugiyono. 2006. Metode Penelitian Pendidikan "Pendekatan Kuantitatif, Kualitatif, dan R\&D". Bandung: Alfabeta

Suherman, Erman. dkk. 2003. Strategi Pembelajaran Matematika Kontemporer. Bandung: Jurusan Matematika FMIPA UPI

Sumarmo, Utari. 2010. Berfikir Dan Disposisi Matematik: Apa, Mengapa, Dan Bagaimana Dikembangkan Pada Peserta Didik. Artikel tersedia pada https://ml.scribd.com/doc/76353753/Berfikir-Dan-Disposisi-MatematikUtari. Bandung. FMIPA UPI 